\title{
Working Capital Management and Firm Profitability: Evidence from Industry Products and Services Enterprises Listed on the Vietnam Stock Market
}

\author{
Hung Manh Nguyen \\ University of Transport Technology, 54 Trieu Khuc Street, Ha Noi, Viet Nam
}

\begin{abstract}
The purpose of this study is to find out the effect of working capital management on company profitability. In light of this objective the study adopts quantitative approaches to test a series of research hypotheses. A sample of 86 industry products and services enterprises listed on the Vietnam stock market was used for a period from 2009 to 2019 with the total of 946 observations. The findings of the study showed that, there exists a highly significant negative relationship between average collection period and profitability indicating that a decrease in the number of days a firm receives payment from sales affects the profitability of the firm positively. This study will provide a general agenda to researchers, strategy makers, investors and professionals to guide future researches.
\end{abstract}

Keywords: Working Capital, Profitability, Vietnam

DOI: $10.7176 / \mathrm{EJBM} / 12-27-12$

Publication date:September $30^{\text {th }} 2020$

\section{Introduction}

Business plays a vital role in the capital formation of a country and people consider it as the life blood of a growing economy. Therefore, it is very important to manage business effectively and efficiently. One of the major issues encountered by fund managers today is not just the procurement of funds but also their meaningful deployment to generate maximum returns. Working capital management is an important corporate financial decision since it directly affects the profitability of the firm. Working capital management efficiency is vital especially for manufacturing firms, where a major part of assets is composed of current assets especially inventory and trade receivables (Arunkmar and Ramanan, 2013).

Working capital of the firm helps to maintain its liquidity, solvency and profitability (Mukhopadhyay, 2004). The significance of managing working capital of a firm cannot be denied (Filbeck \& Krueger, 2005). It has direct impact on both the profitability and level of desired liquidity of a business (Rehman \& Nasr, 2007). If a company invests heavily in working capital more than its needs, then the profits which can be generated by investing these resources in fixed or long term assets will be decrease. Moreover the firm will have to breathe cost of inventory for longer periods as well as the cost of handling the stock (Arnold, 2008).

Profitability can be termed as the rate of return on assets. If there will be an unjustifiable over investment in current assets, this would negatively affect the rate of return on investment (Raheman and Nasr, 2007). The basic purpose of managing working capital is controlling of current financial resources of a firm in such a way that a balance is created between profitability of the firm and risk associated with that profitability (Lazaridis and Tryfonidis, 2006).

Working capital management plays an important role in managerial enterprise, it may impact to success or failure of firm in business because working capital management affect to the profitability of the firm. Indeed, a lot of research (Mathuva, 2010; Lazaridis and Tryfonidis, 2006; Falope and Ajilore, 2009; Mansoor and Muhammad, 2012; Naimulbari, 2012; Raheman and Nasr, 2007) have been conducted in different countries to show the effects of working capital components on firm's profitability. However, since Vietnam differs from developed and other developing countries in terms of capital markets, economy and infrastructural development, this limited evidence in the context of Vietnam along with the importance of working capital management calls for research on the effects of working capital management on company's profitability. Working capital management and profitability definitely have relation with each other. Previous research is available on this relationship but the sector i.e. Industry products and services sector. Working capital is important part of business activities of a firm. For the industry products and services sector as well, working capital management is of crucial part. So, the objective of this study is to find out "Does efficient working capital management have any impact on the profitability of firms of industry products and services of Vietnam?"

The uniqueness of this research is to identify the impact of working capital to profitability of industry products and services enterprises listed on the Vietnam stock market.

\section{Literature review}

Many previous researches have indicated the relationship between working capital management and profitability of firm in different environments. Shin and Soenen (1998) used a sample of 58,985 firm's years covering the 
period 1975-1994 in order to investigate the relationship between net-trade cycle that was used to measured efficiency of working capital management and corporate profitability. In all cases, they found a strong negative relationship between the length of the firm's net-trade cycle and its profitability.

Deloof (2003) investigated the relationship between working capital management and corporate profitability for a sample of 1,009 large Belgian non-financial firms for the 1992-1996 periods. The result from analysis showed that there was a negative between profitability that was measured by gross operating income and cash conversion cycle as well number of day's accounts receivable and inventories. He suggested that managers can increase corporate profitability by reducing the number of day's accounts receivable and inventories. Less profitable firms waited longer to pay their bills.

Lazaridis and Tryfonidis (2006) have investigated relationship between working capital management and corporate profitability of listed company in the Athens Stock Exchange. A sample of 131 listed companies for period of 2001-2004 was used to examine this relationship. The result from regression analysis indicated that there was a statistical significance between profitability, measured through gross operating profit, and the cash conversion cycle. From those results, they claimed that the managers could create value for shareholders by handling correctly the cash conversion cycle and keeping each different component to an optimum level.

Raheman and Nasr (2007) have selected a sample of 94 Pakistani firms listed on Karachi Stock Exchange for a period of 6 years from 1999-2004 to study the effect of different variables of working capital management on the net operating profitability. From result of study, they showed that there was a negative relationship between variables of working capital management including the average collection period, inventory turnover in days, average collection period, cash conversion cycle and profitability. Besides, they also indicated that size of the firm, measured by natural logarithm of sales, and profitability had a positive relationship.

Almazari (2013) concluded the relationship between the working capital management (WCM) and the firms' profitability for the Saudi cement manufacturing firm. The results showed that Saudi cement industry's current ratio was important liquidity indicator which effected profitability, the cement firms must choose a trade-off between these two objectives so that, neither the liquidity nor profitability suffers. The sample was taken 8 Saudi cement manufacturing companies listed in the Saudi Stock Exchange for period of 5 years from 2008-2012.

Nyabwanga et al. (2012) examined the impact of working capital management on performance of SSEs in Kisi South District, the findings of the study were that, working capital management practices were low among SSEs as majority had not adopted formal working capital management routines and their performance was on a low side.

Mehmood \& Ullah (2010) concluded that to improve profitability of a firm and sufficient liquidity to meet short term liabilities sit fall due are two objects of working capital management WCM initiative release capital and increase profitability that can be used for investments or to reduce the debt. It also works for to improve efficiency in the areas of receivables, inventories and payables.

Ahmad et al. (2013) investigated the effect of working capital management on the operating liquidity of manufacturing companies listed on Karachi Stock Exchange, Pakistan. The study concluded that operational liquidity of manufacturing firms can be improved by using proper policies and strategies of working capital management.

Afeef (2011) in his paper on investigating the effect of WCM on Profitability of SME's in Pakistan based on a sample of 40 Pakistani small and medium enterprises (SME's) listed in Karachi Stock Exchange for a period of six years from 2003 to 2008 leading to a total of 240 observations. The Correlation matrix of the pooled data of firms observed, significant negative relationship of the Inventory Conversion Period and the Receivable Collection

Based on the literature review, the following research gaps are pointed out:

First, the sign of working capital management and profitability relationship is inconsistent in the studies. Empirical studies from different economies, at different times and different research methods bring diverse and mixed research results. Therefore, this topic needs further research to enrich the empirical evidences.

Second, the studies of this topic are not diverse and updated in Vietnam.

There are various papers on the relationship between working capital management and firm performance in a wide range of countries such as Europe and North America (Shin and Soenen ,1998), Belgian (Deloof, 2003), Athens (Lazaridis and Trifonidis, 2006), Pakistan (Afeef, 2011) ,Bangladesh (Ahmed et al., 2017), Japan (Nobanee et al., 2009), Malaysia (Azhar and Noriza, 2010). However, there are only a few studies in Vietnam (Dong and Su, 2010; Tu and Nguyen, 2014), using old data sets before 2012.

\section{Research method}

3.1. Data and research sample

Data used in the study were collected from the Financial Statements of 86 industry and service enterprises listed on Vietnam's stock market from 2009 to 2019 by Media Company. and Stoxplus Finance provided. The sample consisted of 86 listed companies in the industry and a total of 946 observations between 2009 and 2019. 


\subsection{Research models}

The model was chosen based on rationality based on theoretical reasoning and on the basis of previous studies on the impact of working capital management on the profitability of the business. At the same time, the author adds the performance variable using fixed capital to study the impact of fixed capital management on the profitability of the business.

Figure 1. Research model of the impact of working capital management on the profitability of the business

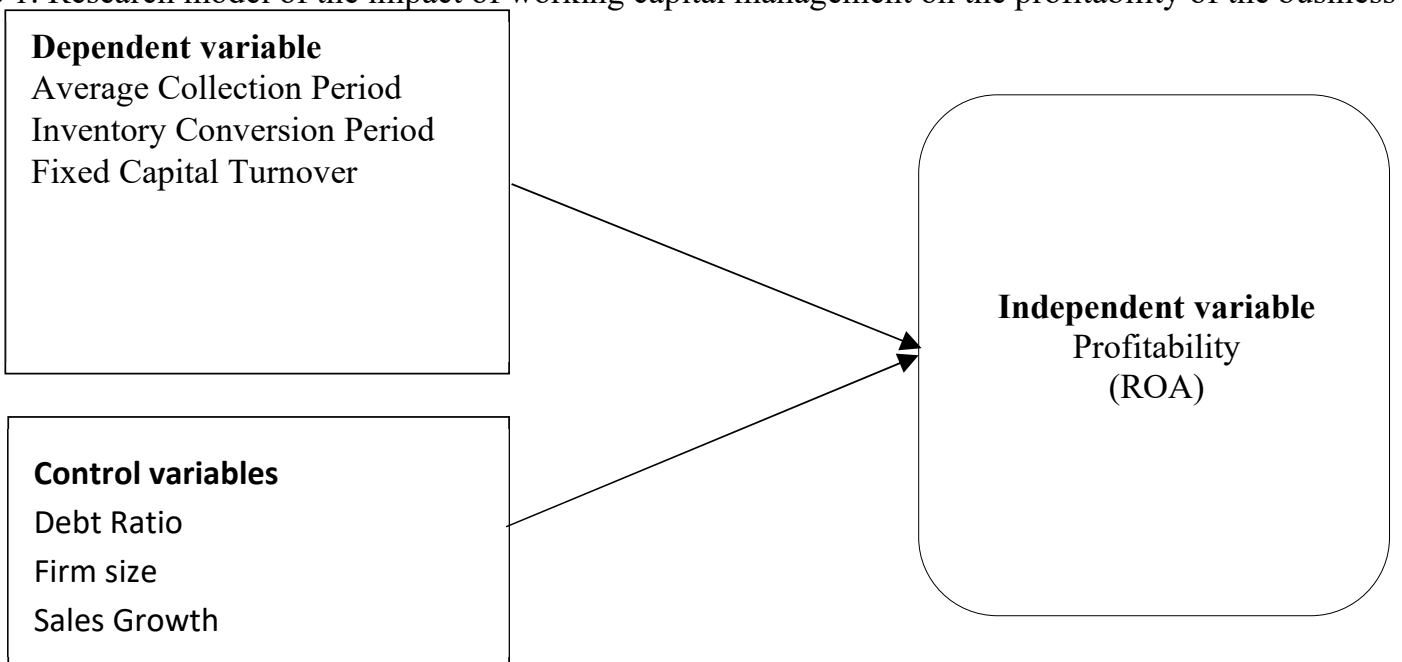

Figure 1. Research model of the impact of working capital management on the profitability of the business

The regression model (Figure 1) is used by the authors to assess the impact of business capital management on the profitability of listed companies and industrial services. In which the variables of the model are presented in Table 1.

Table 1. Description of variables in the model

\begin{tabular}{|l|c|l|}
\hline \multicolumn{1}{|c|}{ Variable name } & Code & \multicolumn{1}{c|}{ Notes } \\
\hline Profitability & ROA & ROA = Net income/ Average total assets \\
\hline Average Collection Period & ACP & $365 \times$ Average net receivables / Net sales \\
\hline $\begin{array}{l}\text { Inventory Conversion } \\
\text { Period }\end{array}$ & ICP & $365 \times$ inventory / cost of sales \\
\hline Fixed Capital Turnover & FCT & Net sales / Average fixed assets \\
\hline Debt Ratio & DR & Total liabilities / total assets \\
\hline Firm size & SIZE & Firm size measured by log of total assets \\
\hline Sales Growth & GR & $\begin{array}{l}\text { (Current period net sales - previous period net sales)/ previous period net } \\
\text { sales }\end{array}$ \\
\hline Current Ratio & CR & Current assets/ current liabilities \\
\hline
\end{tabular}

\section{Dependent variable}

Profitability (ROA): This indicator provides information on the profitability of the business, and also shows the level of efficiency of business capital. This indicator is used as a dependent variable in the research of many authors on the impact of working capital management on the profitability of enterprises, such as the research of Sharma and Kumar (2011), Karaduma et. al (2011), Samiloglu and Demirgunes (2008), Nazir and Afza (2009) and Wang (2002).

\section{Independent variable :}

Average Collection Period (ACP)

The average collection period is the average period from when businesses sell goods until they collect money from customers. The shorter the average collection period, shows that the customer appropriating capital of the enterprise only takes place in a short period of time, or in other words, businesses recover money quickly, improving the ability to ensure the source of money. necessary for my operation. Short-term average collection period is associated with low risk, due to its ability to recover money fast and less bad debts, but at the same time has an adverse effect on the size of revenue (Karamath, 1989).

Inventory Conversion Period (ICP)

Average time required for raw materials and input goods to be converted into finished products and sold to customers. The shortening of rotation of inventory capital helps businesses accelerate production and business processes, increase sales, and save costs related to storage and preservation of inventories.

Fixed Capital Turnover (FCT)

The efficiency of using fixed capital is an indicator reflecting the situation of fixed capital management of 
enterprises, calculated by dividing net revenue by average fixed capital. The higher this indicator, the better the performance of fixed capital businesses are.

Control variables: Control variables selected by the authors include: Debt ratio, Firm size, Net revenue growth rate and Current solvency coefficient.

Debt Ratio (DR)

The debt ratio indicates the level of loan usage in the total capital of the enterprise. Debt ratio is calculated by Total debt on total assets of the enterprise. The higher the debt ratio, the lower the level of financial autonomy of enterprises and the higher the financial risk of enterprises. However, if using a lot of loans, businesses also get certain advantages, especially get a tax shield from interest (Interest tax shield).

Firm size (SIZE)

Many studies have shown that firm size is one of the factors affecting business results. Large-sized enterprises often perform business activities with better results than small-scale businesses because large enterprises are capable of carrying out large projects and have high competitiveness (Jose, Lancaster and Stevens). In these studies, the author chooses the natural logarithm of total assets as a measure of firm size.

Sales Growth (GR)

Typically, the higher the revenue, the higher the profitability of the business, the better the business results of the business. At the same time, previous studies also showed the impact of net revenue growth on the profitability of businesses.

Current Ratio (CR)

Current solvency measures the ability of enterprises to pay short-term debts with short-term assets. High current solvency shows that enterprises have good ability to convert short-term assets into cash to pay short-term debts or low risks. And if this indicator is low, especially lower than 1, it shows that the enterprise has high risks and its ability to repay debts is weak. In previous studies, current solvency has an impact on the profitability of businesses.

\subsection{Research hypothesis}

Based on previous studies and the theories, we propose the hypothesis as follows:

$\mathbf{H}_{1}$ : There is negative relationship between average collection period and profitability.

$\mathbf{H}_{2}$ : There is negative relationship between inventory conversion period and profitability

$\mathbf{H}_{3}$ : There is between Fixed capital turnover and profitability.

\subsection{Data analysis}

The authors used quantitative research method with the support of Stata15 statistical software. With the characteristics of table data, the authors have conducted tests to check the validity of the model and verify the compliance with important assumptions such as: no autocorrelation, constant variance, multiple collinearity.

To assess the impact of business capital management on the profitability of industry enterprises and industrial services listed on Vietnam's stock market, the authors used descriptive statistical analysis method, correlation matrix analysis and regression model estimation. In estimating the regression model using table data can be done through three methods, namely least squares, fixed effect model and random effect model. To select the appropriate model, the authors performed the Hausman test, White test.

\section{Research results}

4.1. Descriptive statistics

Table 2. Descriptive statistics

\begin{tabular}{|c|c|c|c|c|c|}
\hline Variables & Obs & Mean & Std. Dev & Max & Min \\
\hline ROA & 946 & 0.068 & 0.10 & -1.69 & 0.72 \\
\hline ACP & 946 & 132.26 & 453.27 & 7.09 & 11945 \\
\hline ICP & 946 & 77.27 & 186.57 & 0 & 3795 \\
\hline FCT & 941 & 19.47 & 63.39 & 0.28 & 918 \\
\hline DR & 946 & 0.48 & 0.23 & 0.04 & 2.03 \\
\hline SIZE & 946 & 26.65 & 1.20 & 23.46 & 30.6 \\
\hline GR & 946 & 0.31 & 4.26 & -0.95 & 127.5 \\
\hline CR & 946 & 2.25 & 2.28 & 0.19 & 19.03 \\
\hline
\end{tabular}

Table 2 presents descriptive statistics including mean, median, standard deviation as well as minimum and maximum values of variables included in the model. The descriptive statistical analysis results presented in Table 2 show that with 946 observations of 86 sample companies over the 11-year period, the average ROA was $6.8 \%$ with a standard deviation of $10 \%$, and enterprises with the lowest targets are $-169 \%$ and enterprises with the highest targets are $72 \%$. The average level of the criteria the collection of the average collection period, inventory conversion period of the whole sample are 132 days and 77 days respectively. Enterprises in the sample had 
average capital use efficiency of 19.47 times; the average debt ratio is 0.48 ; the average value of logarithm total assets is 26.65 ; the average sales growth rate is $31 \%$ and the current ratio is 2.25 .

\subsection{Correlation analysis}

Table 3. Correlation coefficient

\begin{tabular}{|c|c|c|c|c|c|c|c|c|}
\hline & ROA & ACP & ICF & FCT & DR & SIZE & GR & CR \\
\hline ROA & 1 & & & & & & & \\
\hline $\mathrm{ACP}$ & -0.20 & 1 & & & & & & \\
\hline ICF & -0.17 & 0.33 & 1 & & & & & \\
\hline $\mathrm{FCT}$ & -0.03 & -0.02 & -0.02 & 1 & & & & \\
\hline DR & -0.51 & 0.12 & 0.26 & 0.15 & 1 & & & \\
\hline SIZE & -0.03 & 0.07 & 0.08 & 0.1 & 0.23 & 1 & & \\
\hline GR & -0.01 & -0.01 & -0.02 & 0.17 & 0.06 & 0.06 & 1 & \\
\hline CR & 0.27 & 0.02 & -0.09 & -0.06 & -0.65 & -0.22 & -0.02 & 1 \\
\hline
\end{tabular}

Table 3 shows the correlation coefficients between the dependent variables and the independent variables. The correlation coefficient between the independent variables is not greater than 0.8 , so there is no multicollinearity between the variables (Cohen, 1988). Average collection period (ACP), inventory capital turnover (ICF), fixed capital operating performance (FCT), debt ratio (DR), firm size (SIZE), growth rate revenue (GR) is negatively correlated with the profitability (ROA) variable, while the current solvency (CR) variables are positively correlated with the profitability (ROA).

\subsection{Regression analysis results}

Table 4 presents models that describe regression results and test results when selecting the appropriate model.

Table 4. Regression results

\begin{tabular}{|c|c|c|c|c|}
\hline \multirow[t]{2}{*}{ Variable } & \multirow[t]{2}{*}{ VIF } & \multicolumn{3}{|c|}{ Regression coefficients } \\
\hline & & POLS & FEM & REM \\
\hline $\mathrm{ACP}$ & 1.14 & $-0.0000902 * * *$ & $-0.0000850 * * *$ & $-0.0000848^{* * *}$ \\
\hline ICP & 1.19 & 0.00000649 & 0.0000135 & 0.0000154 \\
\hline FCT & 1.06 & 0.0000630 & $0.000108 * *$ & $0.0000922 * *$ \\
\hline DR & 1.94 & $-0.247 * * *$ & $-0.388 * * *$ & $-0.348 * * *$ \\
\hline Size & 1.08 & $0.00733 * * *$ & $0.0118 * *$ & $0.00942 * *$ \\
\hline GR & 1.03 & 0.000296 & 0.000749 & 0.000642 \\
\hline $\mathrm{CR}$ & 1.79 & $-0.00326^{* *}$ & $-0.0102 * * *$ & $-0.00911 * * *$ \\
\hline Cons & & 0.00779 & -0.0315 & 0.012 \\
\hline $\mathrm{N}$ & 1.32 & 941 & 941 & 941 \\
\hline R-sq & & 0.293 & 0.288 & 0.288 \\
\hline Significance & & $F(7,933)=55.36$ & $=48.97$ & Wald chi2(7) \\
\hline White test & & $\begin{aligned} \text { Chi } 2(35) & =781.51 \\
\text { Prob }>\text { Chi } 2 & =0.0000\end{aligned}$ & & \\
\hline Hausman test & & & $\operatorname{chi} 2(7)=22$ & Prob $>$ chi $2=$ \\
\hline
\end{tabular}

$* \mathrm{p}<0,1 * * \mathrm{p}<0,05 * * * \mathrm{p}<0,01$

Multicollinearity test results show that the magnification coefficient of VIF variance are $<10$, the model has no multicollinearity phenomenon. The largest VIF is 1.94 , indicating that the possibility of multicollinearity is not significant. The White test indicates that the model has heterogeneity ( $\mathrm{p}$-value $<5 \%$ ). Therefore, the OLS Pool model is not suitable. Hausman test for $\mathrm{p}$-value $=0.0023<0.05$ rejects Ho, so using fixed impact model (FEM) to evaluate the impact of business capital management on the profitability of businesses List of industrial products and services.

The Prob value of the independent variables such as average collection period, debt ratio and current ratio is currently at $\mathrm{p}<0.01$, which are the factors that have the largest impact on profitability of enterprise. The current average collection period, debt ratio and current ratio are inversely correlated with the profitability of listed businesses and industrial services. The performance factor of fixed capital turnover, firm size with $\mathrm{p}<0.05$ shows that this factor also has a moderate correlation to the profitability of the business. The performance of fixed capital turnover and firm size are positively correlated with the profitability of listed businesses and industrial services. The remaining factors include the Inventory Conversion Period, the sales growth has no correlation with the profitability of listed businesses industrial services ( $p$-value of these factors are $>0.1$ ).

\section{Conclusion}

This study was aimed to detect the impact of working capital management on profitability of industry products 
and services sector of listed enterprises of Vietnam. For this purpose regression model was applied and different assumption test was also applied for the model fitness. The result shows that there is statistically significant negative relationship between profitability and average collection period (accepted $\mathrm{H}_{1}$ ). The negative relationship between average collection period and profitability suggests that an increase in the number of day's accounts receivable by 1 day is associated with a decline in profitability. Managers can increase the company's profitability by reducing these days. Through this, managers can improve profitability by reducing the credit granted to their customers (Lazaridis and Tryfonidis, 2006). Other authors with the same results of negative relationship between profitability and average collection period include (Mathuva, 2010; Lazaridis and Tryfonidis, 2006; Falope and Ajilore, 2009; Mansoor and Muhammad, 2012; Naimulbari, 2012, Raheman and Nasr, 2007; Dong, 2010; Arunkmar and Ramanan, 2013). The inventory conversion period has no correlation with the profitability of listed businesses industrial services (rejected $\mathrm{H}_{2}$ ).

Besides, the fixed capital turnover has positive relationship with the profitability of listed businesses industrial services (rejected $\mathrm{H}_{3}$ ). This result indicates enterprises implement measures to improve the efficiency of using fixed assets can improve ROA.

\section{References}

Afeef, M. (2011). Analyzing the Impact of Working Capital Management on the Profitability of SME's in Pakistan. International Journal of Business and Social Science, 2(22).

Almazari, A. A. (2013). The relationship between working capital management and profitability: Evidence from Saudi cement companies. British Journal of Economics, Management \& Trade, 4(1), 146-157.

Arnold, G. (2008). Corporate financial management 4th edition. Pearson education limited; New York

Arunkumar O.N \& Ramanan T.R (2013) Working Capital Management and profitability: A Sensitivity Analysis. International Journal of Research and Development: A Management review. Vol 2, pp 52 - 58

Arunkumar, O. N., \& Ramanan, T. R. (2013). Working capital management and profitability: A sensitivity analysis. International Journal of Research and Development, 2(1), 52-58.

Brigham, F. and Houston, F. (2003), 'Fundamentals of financial management', 10th ed. McGraw-Hill Inc: New York

Deloof M (2003), 'Does working capital management affect profitability of Belgian firms', Journal of Business Finance and Accounting, Vol 30, No. 3 \&4, pp. 573-588.

Falope, O. I, Ajilore O. T (2009), “ Working capital management and corporate profitability: evidence from panel data analysis of selected quoted companies in Nigeria", Research Journal of Business Management, vol.3: pp. 73-84.

Filbeck, G., \& Krueger, T. M. (2005). An analysis of working capital management results across industries. American journal of business.

Lazaridis, I. and Tryfonidis, D. (2006), 'Relationship between working capital management and profitability of listed companies in the Athens stock exchange', Journal of Financial Management and Analysis, Vol 19(1)

Lazaridis, I., \& Tryfonidis, D. (2006). Relationship between working capital management and profitability of listed companies in the Athens stock exchange. Journal of financial management and analysis, 19(1).

Mansoori, E. and Dr. Muhammad (2012), “ The Effect of Working Capital Management on Firm's Profitability: Evidence from Singapore" Interdisciplinary Journal of Contemporary Research in Business, Vol 4, No 5, pp $472-486$

Mathuva, D. M. (2010) “The Influence of Working Capital Management Components on Corporate Profitability: A Survey on Kenyan Listed Firms", Research Journal of Business Management, 4(1): 1-11.

Naimulbari,K. (2012). A research paper on "the impact of working capital management on profitability" of pharmaceuticals sector in Bangladesh.

Nyamao, N. R., Patrick, O., Martin, L., Odondo, A. J., \& Simeyo, O. (2012). Effect of working capital management practices on financial performance: A study of small scale enterprises in Kisii South District, Kenya. African journal of business management, 6(18), 5807-5817.

Raheman, A. and Nasr M., (2007), 'Working capital management and profitability - case of Pakistani fi rms', International Review of Business Research Papers

Raheman, A., \& Nasr, M. (2007). Working capital management and profitability-case of Pakistani firms. International review of business research papers, 3(1), 279-300.

Shin, H. H., \& Soenen, H. L. (1998). Efficiency of working capital and corporate profitability. 